\title{
Surface soil and subsoil acidity in natural and managed land-use systems in the humid tropics of Peninsular India
}

\author{
K. M. Nair ${ }^{1}$, K. S. Anil Kumar ${ }^{1}$, M. Lalitha ${ }^{1, *}$, Shivanand ${ }^{1}$, \\ S. C. Ramesh Kumar ${ }^{1}$, S. Srinivas ${ }^{1}$, Arti Koyal ${ }^{1}$, S. Parvathy ${ }^{1}$, K. Sujatha ${ }^{1}$, \\ C. Thamban', Jeena Mathew ${ }^{2}$, K. P. Chandran², Abdul Haris ${ }^{2}$, \\ V. Krishnakumar², V. Srinivasan ${ }^{3}$, Jessy ${ }^{4}$, James Jacob ${ }^{4}$, J. S. Nagaraj ${ }^{5}$, \\ Maria Violet D'Souza ${ }^{5}$, Y. Raghuramulu ${ }^{5}$, R. Hegde ${ }^{1}$ and S. K. Singh ${ }^{1}$ \\ ${ }^{1}$ Regional Centre, ICAR-National Bureau of Soil Survey and Land Use Planning, Hebbal, Bengaluru 560024 , India \\ ${ }^{2}$ ICAR-Central Plantation Crops Research Institute, Kasaragod 671 124, India \\ ${ }^{3}$ ICAR-Indian Institute of Spices Research, Kozhikode 673 012, India \\ ${ }^{4}$ Rubber Research Institute of India, Kottayam 686 009, India \\ ${ }^{5}$ Coffee Research Institute, Chikmagalur 577 117, India
}

\begin{abstract}
Natural forests and managed plantations constitute the largest land-use systems in the humid tropics of southwestern parts of Peninsular India comprising the Western Ghats and coastal plain. Soils therein are naturally acidic and the acidity is enhanced in managed land-use systems through inputs of chemical fertilizers. Plant nutrient deficiencies and mineral toxicities constrain crop production in acid soils. Surface soil and subsoil acidity in forest, coffee, rubber and coconut land-use systems was evaluated. The spatial pattern of surface soil and subsoil acidity pointed to low intensity of acidification in Malnad region of Karnataka, moderate acidity in northern Kerala and strong acidity in southern Kerala. Among the land-use systems studied, soils under natural forests and coffee plantations were only slightly acidic in surface soil and subsoil, whereas rubber- and coconut-growing
\end{abstract}

soils were strongly acidic. Both natural and managed land-use systems, however, had strongly acid reaction in surface soil and subsoil in southern Kerala. Biomass production and crop yield are constrained in strongly acid soil by toxic levels of aluminium (Al) on soil exchange complex $\left(>0.5 \mathrm{cmol}(+) \mathrm{kg}^{-1}\right.$ soil $)$ and depletion of basic cations of calcium, magnesium and potassium (base saturation less than $50 \%$ or Al saturation more than $50 \%$ ). Surface soil acidity can be ameliorated by incorporating liming materials into surface soils. In case of subsoil acidity gypsum too should be incorporated. Under humid climate partial solubility of gypsum permits movement of calcium into the subsoil layers, wherein calcium replaces the aluminium on exchange complex and sulphate radical precipitates the aluminium by formation of aluminium sulphate.
Keywords: Base saturation, humid tropics, land-use systems, surface soil and subsoil acidity.

GLOBALLY acid soils cover large areas in the cold, humid northern belt and the hot, humid tropics ${ }^{1}$. Soils in around $30 \%$ of the world's arable lands are acidic ${ }^{1-3}$. In India, $30 \%$ of the total cultivable area has acid soil, mainly distributed in the humid regions of southwestern and northeastern parts of the country and in the Himalayas ${ }^{4}$. Soils of the humid tropics are naturally acidic, albeit moderately. High rainfall, leaching of bases, mineralization of organic matter, external inputs of acid-forming chemical fertilizers and inappropriate agriculture practices are the major reasons for soil acidification and its intensification ${ }^{5-7}$. Acid soils are constraining environments for plants and macroand micro-organisms inhabiting them. Poor soil fertility

*For correspondence. (e-mail: mslalit@yahoo.co.in) and productivity of acid soils is due to a combination of mineral toxicities (aluminium and manganese) and deficiencies (phosphorus, potassium, calcium, magnesium, zinc, boron, etc.). Surface soil acidity and its effect on crop production are well known for several centuries ${ }^{8}$. Recognition of subsoil acidity and its consequences, however, is quite recent, dating back to just five decades ${ }^{9,10}$.

Subsoil acidity refers to acidification below the plough layer, in general below $20 \mathrm{~cm}$. It is one among the many soil-related constraints in hot, humid, tropical climatic regions. Subsoil acidity causes significant yield reduction in tropical acid soils because of high content of soluble $\mathrm{Al}$ and $\mathrm{Mn}$ or low plant-available calcium ${ }^{11}$, inhibiting physiological and biological activities ${ }^{7,12}$, root development $^{13}$ and uptake of nutrients such as $\mathrm{P}, \mathrm{Ca}, \mathrm{Mg}, \mathrm{K}$ and $\mathrm{Mo}^{14,15}$ as well as water ${ }^{16,17}$. It is the main chemical impediment for most deep-rooted and perennial crops which require uptake of nutrients and water from subsoil layers ${ }^{18}$. 


\section{RESEARCH ARTICLES}

This article discusses surface and subsoil acidity with a focus on natural and managed land-use systems of tropical, hot, humid region of southwestern India, as well as the possible consequences of soil acidity on crop production.

\section{Materials and methods}

Southwestern Peninsular India comprising the Western Ghats and western coastal plain in the states of Tamil Nadu, Kerala and Karnataka (Figure 1) experiences tropical hot, humid climate ${ }^{19}$. Forests and plantations of rubber, coffee and coconut are major land-use systems in the region. Soil quality monitoring sites (SQMS) were established for these land-use systems ${ }^{20,21}$. At each site soil profiles were excavated, studied for morphology ${ }^{22}$ and sampled for laboratory examination.

Horizon-wise soil samples were analysed for physical and chemical properties following standard procedures. Soils were classified according to the soil taxonomy ${ }^{22}$. Soil reaction $\left(\mathrm{pH}\right.$ in water $\left(\mathrm{pH}_{(\mathrm{w})}\right)$ and in $0.01 \mathrm{M} \mathrm{CaCl} \mathrm{Ca}_{2}$ $\left.\left(\mathrm{pH}_{(\mathrm{Ca})}\right)\right)$ and electrical conductivity $(\mathrm{EC})$ were estimated by potentiometric and conductometric methods respectively $^{23}$. Particle size distribution in the fine earth $(<2 \mathrm{~mm})$ was determined by sieving and use of International pipette ${ }^{24}$. Exchangeable bases were extracted by neutral normal ammonium acetate ${ }^{25}$ and determined by atomic absorption spectrophotometry. Exchangeable hydrogen and aluminium were determined by extraction with $1 \mathrm{~N} \mathrm{KCl}$ (ref. 23) followed by titration with standard alkali. Base saturation and aluminium saturation were calculated as follows:

Base saturation $(\%)=($ Total bases $/$ CEC $) \times 100$,

Aluminium saturation $(\%)=[$ extracted $\mathrm{Al} /$

$$
\begin{aligned}
& (\text { exchangeable } \mathrm{Ca}+\mathrm{Mg}+\mathrm{K}+\mathrm{Na} \\
& + \text { extracted } \mathrm{Al})] \times 100,
\end{aligned}
$$

where exchange $\mathrm{Ca}, \mathrm{Mg}, \mathrm{K}, \mathrm{Na}$, total bases, CEC and extractable $\mathrm{Al}$ are in $\mathrm{c} \mathrm{mol}(+) \mathrm{kg}^{-1}$ soil.

From among the large dataset (183 SQMS) soil analytical data pertaining to 12 SQMS representing the four land-use systems are presented to describe soil quality in the study area and surface soil and subsoil acidity (Tables 1 and 2). The entire data on SQMs for the four land-use systems were used for assessing the variability of soil acidity across these systems as well as spatial variability.

\section{Results and discussion}

\section{Soil quality in the study area}

Soils of the study area, formed under humid tropical climate, are deeply weathered, leached and depleted of bases. These low-activity clay soils are deep, welldrained, strongly acidic, and low in basic cations and per cent base saturation. These soils with subsoil horizons of illuvial clay belong to Ultisol order of soil taxonomy ${ }^{22}$. However, the coastal sandy soils belong to Entisol order (Table 2). Classification of the soil into different taxa at the family level reflects variability in organic matter content, distribution of illuvial clay in subsoil layers, activity of clay, presence or absence of plinthite, clay mineralogy, temperature regime and particle-size class. These soils have kaolinite, goethite, gibbsite and hydroxylinterlayered vermiculites as major minerals in their clay fraction $^{26}$. Table 2 presents the physical and chemical properties of the soils.

The texture of the soil is generally loam in surface layers and clay in subsoil layers due to illuviation of clay

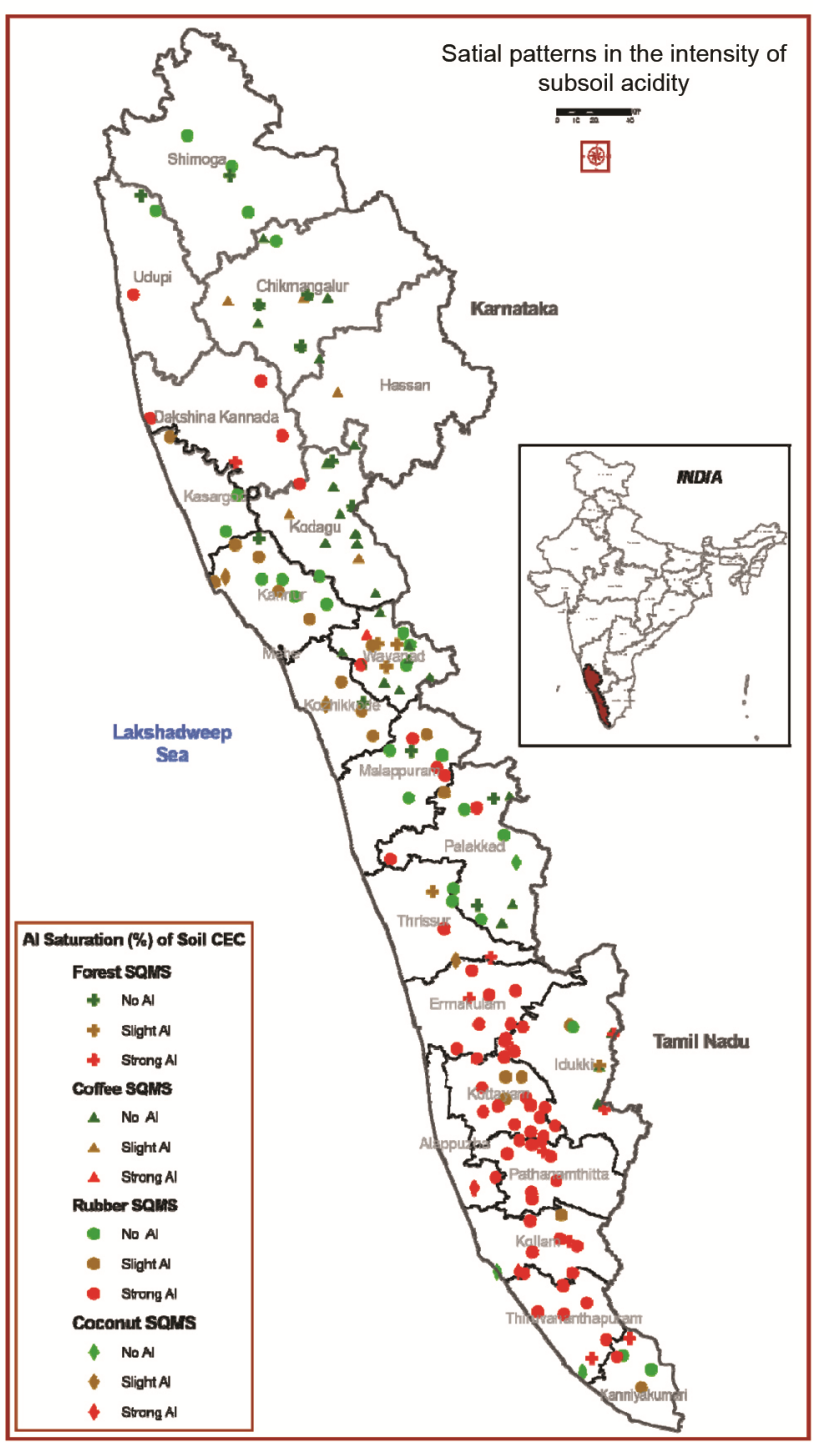

Figure 1. Study area, soil-quality monitoring sites (183 pedon locations) and intensity of Al saturation of cation exchange capacity of soils (slight: $<50 \%$; strong: $>50 \%$ saturation). 
RESEARCH ARTICLES

Table 1. Location and site characteristics of representative soils of four land-use systems

\begin{tabular}{|c|c|c|c|c|c|c|c|}
\hline $\begin{array}{l}\text { Pedon } \\
\text { number }\end{array}$ & District & Latitude (N) & Longitude (E) & $\begin{array}{c}\text { Slope } \\
(\%)\end{array}$ & $\begin{array}{l}\text { Elevation } \\
\text { (m amsl) }\end{array}$ & $\begin{array}{c}\text { Rainfall } \\
\text { (mm) }\end{array}$ & Land use \\
\hline $\mathrm{P} 1$ & Chikmagalur & $13^{\circ} 21^{\prime} 35.1^{\prime \prime}$ & $75^{\circ} 25^{\prime} 28.0^{\prime \prime}$ & $15-25$ & 805 & 2500 & Forest \\
\hline $\mathrm{P} 2$ & Ernakulam & $10^{\circ} 06^{\prime} 32.5^{\prime \prime}$ & $76^{\circ} 29^{\prime} 59.0^{\prime \prime}$ & $1-3$ & 25 & 3178 & Forest \\
\hline $\mathrm{P} 3$ & Thivurananthapuram & $08^{\circ} 25^{\prime} 23.7^{\prime \prime}$ & $77^{\circ} 06^{\prime} 37.7^{\prime \prime}$ & $5-10$ & 52 & 1658 & Forest \\
\hline $\mathrm{P} 4$ & Chikmagalur & $13^{\circ} 22^{\prime} 41.0^{\prime \prime}$ & $75^{\circ} 15^{\prime} 53.1^{\prime \prime}$ & $1-5$ & 695 & 2500 & Coffee \\
\hline P5 & Wayanad & $11^{\circ} 44^{\prime} 03.1^{\prime \prime}$ & $75^{\circ} 51^{\prime} 00.0^{\prime \prime}$ & $15-25$ & 779 & 3777 & Coffee \\
\hline P7 & Udupi & $13^{\circ} 24^{\prime} 23.6^{\prime \prime}$ & $74^{\circ} 46^{\prime} 04.2^{\prime \prime}$ & $3-5$ & 38 & 3000 & Rubber \\
\hline P8 & Wayanad & $11^{\circ} 04^{\prime} 28.2^{\prime \prime}$ & $75^{\circ} 56^{\prime} 54.3^{\prime \prime}$ & $10-15$ & 773 & 4182 & Rubber \\
\hline P9 & Kottayam & $09^{\circ} 34^{\prime} 34.4^{\prime \prime}$ & $76^{\circ} 34^{\prime} 02.0^{\prime \prime}$ & $10-15$ & 30 & 3095 & Rubber \\
\hline $\mathrm{P} 10$ & Kannur & $12^{\circ} 04^{\prime} 55.2^{\prime \prime}$ & $75^{\circ} 15^{\prime} 20.3^{\prime \prime}$ & $1-3$ & 24 & 3669 & Coconut \\
\hline P11 & Alappuzha & $09^{\circ} 12^{\prime} 49.7^{\prime \prime}$ & $76^{\circ} 31^{\prime} 47.6^{\prime \prime}$ & $1-3$ & 1 & 2313 & Coconut \\
\hline $\mathrm{P} 12$ & Kollam & $08^{\circ} 49^{\prime} 33.6^{\prime \prime}$ & $76^{\circ} 44^{\prime} 35.0^{\prime \prime}$ & $3-5$ & 15 & 2358 & Coconut \\
\hline
\end{tabular}

into subsoil layers. Soil structure is weak subangular blocky in surface layers and moderate to strong subangular blocky in subsoil layers. Varying proportions of gravel and plinthite are found in the laterite soils of the study area, except in the soils of highland plateau and Malnad region (hilly terrain of Karnataka, east of the Western Ghats).

Electrical conductivity was extremely low in surface soils and subsoils $\left(0.01-0.64 \mathrm{dS} \mathrm{m}^{-1}\right)$, indicating negligible level of ionizable salts under the intense leaching environment of high rainfall and freely draining soils. Organic carbon content of the soils was generally high, especially in the surface layers. Plantation systems of rubber and coffee with high biomass production and near zero tillage did not result in any significant decline in soil organic matter level compared to forest soils. However, intercropped and tilled lands of coconut plantations had comparatively low levels of soil organic carbon. Soil organic carbon levels were highest in surface soils, but declined gradually with depth. Forest, coffee and rubber plantation soils had fairly high levels of organic carbon, even at a depth of $50 \mathrm{~cm}$ below the surface (Figure 2).

Soil reaction governs many of its chemical and biological properties responsible for ensuring availability of plant nutrients, macro- and microbial abundance and activity, rate of decomposition of organic matter and accumulation or decomposition of toxic materials. The $\mathrm{pH}_{(\mathrm{w})}$ of surface soils ranged from 4.08 to 6.0 with a mean value of 5.30 and $\mathrm{pH}_{(\mathrm{Ca})}$ ranged from 4.04 to 5.6 with mean value of 4.64. Soil $\mathrm{pH}$ both in water and $\mathrm{CaCl}_{2}$ declined considerably in subsoil layers with mean values falling to 5.0 and 4.4 respectively (Figure 2 ). The $\mathrm{pH}$ values indicate very strong acidic reaction of the soils.

The most commonly used measure of subsoil acidity is the estimation of exchangeable acidity (exch. $\mathrm{H}^{+}$and $\mathrm{Al}^{3+}$ ) extracted with $1 \mathrm{~N} \mathrm{KCl}$ (ref. 27), in particular extractable $\mathrm{Al}$, since aluminium toxicity is considered the most important plant-growth limiting factor in strongly acid soils. In highly weathered tropical soils aluminosilicate minerals, both primary and secondary, and Al oxides (gibbsite) constitute a practically inexhaustible source of Al and their large specific surface area facilitates the formation of soluble and exchangeable Al. Since Al in general exists in combination with hydroxyl, the solubility of $\mathrm{Al}$ in the compounds increases in proportion to $\mathrm{H}^{+}$ion concentration $\left(\mathrm{AlOH}+\mathrm{H} \rightarrow \mathrm{Al}+\mathrm{H}_{2} \mathrm{O}\right)$.

Exchangeable hydrogen was negligible in both surface soil and subsoil layers with mean values of 0.22 and

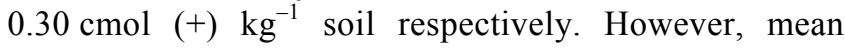
exchangeable aluminium in surface soil and subsoil was 0.56 and $1.12 \mathrm{cmol}(+) \mathrm{kg}^{-1}$ soil respectively. Exchangeable Al was higher in the subsoil roughly corresponding to decline in $\mathrm{pH}$, exchangeable bases and base saturation (Table 2). Aluminium saturation of exchange complex increased in the subsoil layers with a mean of $44 \%$ (Figure 2).

Cation exchange capacity (CEC) of the surface soil layers ranged from 2.12 to $19.6 \mathrm{cmol}(+) \mathrm{kg}^{-1}$ soil with mean value of $11.21 \mathrm{cmol}(+) \mathrm{kg}^{-1}$ soil. In subsoils CEC ranged from 2.08 to $16.76 \mathrm{cmol}(+) \mathrm{kg}^{-1}$ soil with mean value of $7.79 \mathrm{cmol}(+) \mathrm{kg}^{-1}$ soil. The low CEC of soils is a consequence of the dominance of low-activity clay mineral kaolinite. The relatively higher CEC in surface soils and a few immediate subsoil layers (Table 2) is a contribution from organic colloids.

Calcium is the dominant basic cation on the exchange followed by magnesium and very little of potassium and sodium. Mean exchangeable $\mathrm{Ca}, \mathrm{Mg}, \mathrm{K}$ and $\mathrm{Na}$ of surface soils was $3.81,1.07,0.33$ and $0.06 \mathrm{cmol}(+) \mathrm{kg}^{-1}$ soil respectively. The basic cations declined in the subsoil layers with mean value of $1.03,0.57,0.16$ and $0.06 \mathrm{cmol}$ (+) $\mathrm{kg}^{-1}$ soil for $\mathrm{Ca}, \mathrm{Mg}, \mathrm{K}$ and $\mathrm{Na}$ respectively. The mean base saturation as per cent of total exchange capacity for surface soils was 42 and for subsoils 25 (Figure 2).

\section{Land-use systems and soil acidity}

To evaluate the intensity of surface soil and subsoil acidity, the large dataset comprising 29 SQMS for natural forests, 


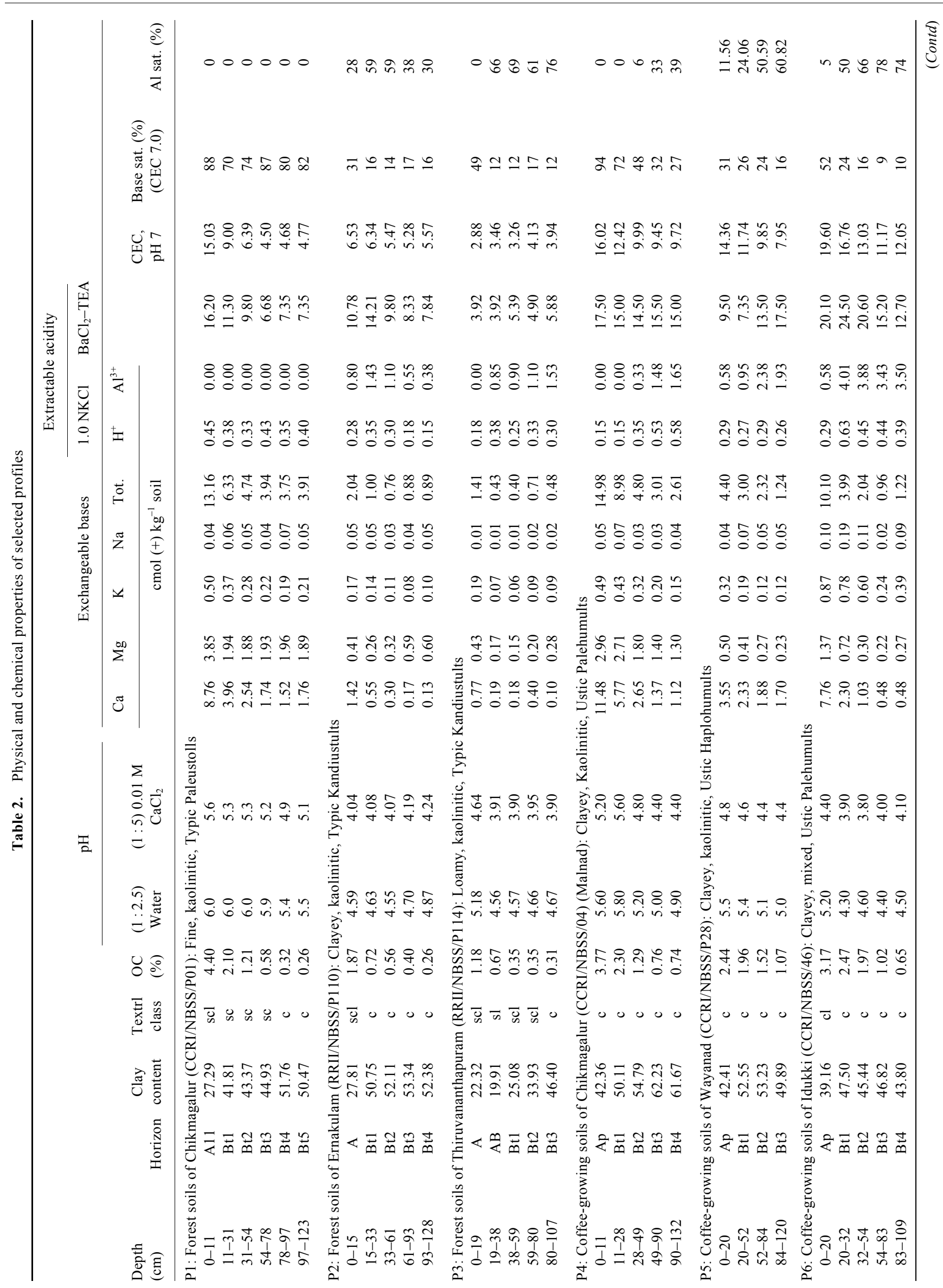




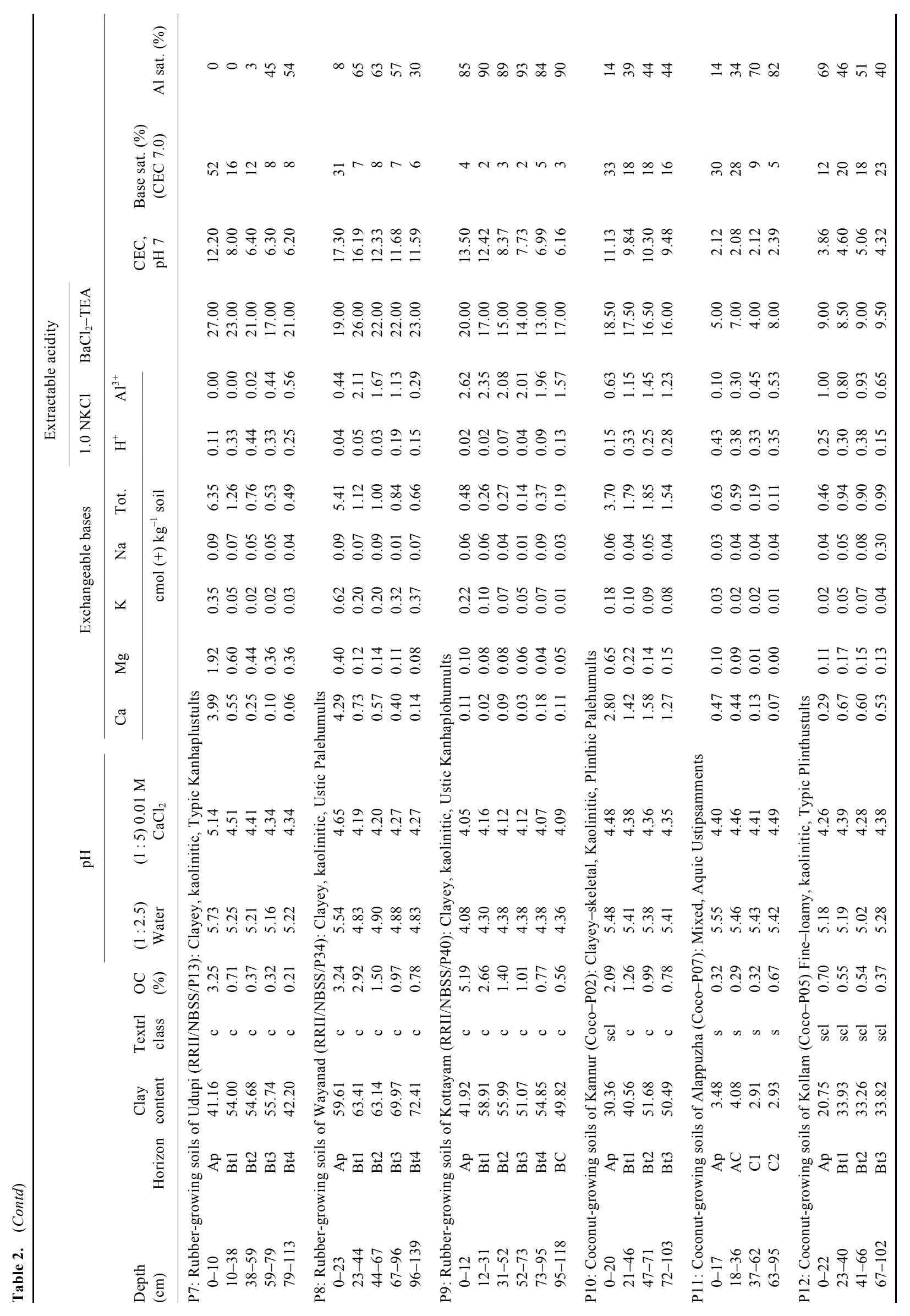

CURRENT SCIENCE, VOL. 116, NO. 7, 10 APRIL 2019 

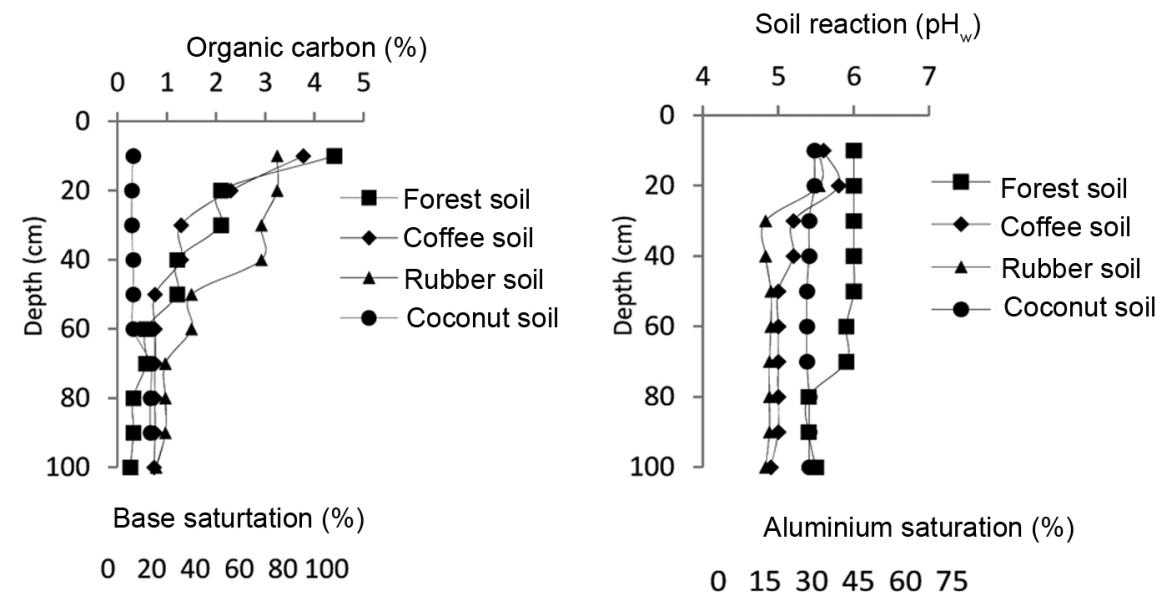

Aluminium saturation (\%)
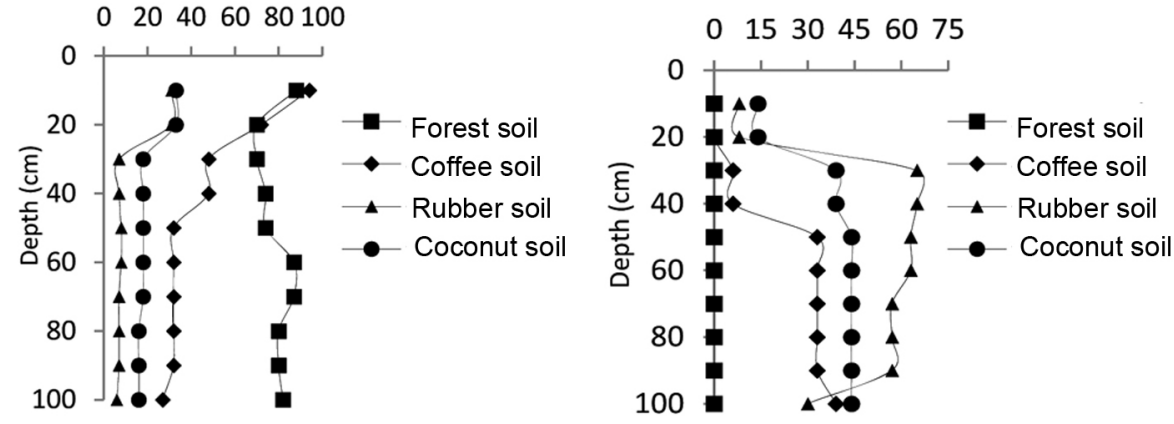

Figure 2. Depth-wise distribution of soil properties in natural and managed land-use systems.

40 for coffee plantations, 100 for rubber plantations and 8 for coconut plantations was analysed. Table 3 presents variability in soil reaction, extractable aluminium, exchangeable calcium and magnesium, base saturation and aluminium saturation of soil exchange complex. Plot of point data in a map of the study area (Figure 1) presents the spatial patterns of intensity of subsoil acidity, measured as extractable aluminium.

Significant differences were discernible in the nature and intensity of soil acidity and related soil quality between the natural and managed land-use systems examined. They are discussed in detail for each land-use system in the following sections.

\section{Natural forests}

The existence of lush evergreen forests in the highly weathered, base-depleted, impoverished soils of the humid tropics is due to the efficient recycling of plant nutrients by deep-rooted trees, their preservation in the organic matter-rich surface soils and rapid turnover by macro- and micro-organisms ${ }^{28,29}$. The nutrients released by decomposition of organic matter are rapidly trapped and absorbed by the fine mat of roots of tropical plant species, against the downward movement with water. Generally, surface soils of natural forests in the tropics are relatively rich in organic carbon, bases and are only mildly acidic. The content of organic carbon and basic cations decreases down the soil profiles and the subsoils are often strongly acidic and low in basic cations (Figures 2-5). Analysis of the dataset of 29 soil profiles from forest lands in the study area provided mean surface soil $\mathrm{pH}_{(\mathrm{w})}$ of 5.67 (range: $4.59-6.00$ ) and subsoil $\mathrm{pH}_{(\mathrm{w})}$ of 5.50 (range: 3.60-6.70). The content of exchangeable bases ( $\mathrm{Ca}, \mathrm{Mg}, \mathrm{K}$ and $\mathrm{Na}$ ), sum of exchangeable bases and base saturation were lower in the subsoil (Table 3 and Figure 3). However, exchangeable Al and Al saturation of exchange complex increased in the subsoil layers.

\section{Coffee land-use system}

Coffee was introduced to India in 1670 and the first large plantation was established in 1840 in Chikmagalur. At present, plantations cover 303,000 ha in Karnataka and Kerala together. Coffee is grown under shade in India. The plantations, mainly established in forested lands, involve clearing the undergrowth alone with most large trees retained. Except during the initial years, soil disturbance is minimal and zero tillage is practised in plantations. Despite the heavy input of acid-producing fertilizers, regular application of lime and dolomite has prevented the acidification of surface soils in coffee plantations. However, carbonate liming materials have very little effect on subsoil acidity due to their very low solubility. Analysis of the dataset of 46 soil profiles from coffee plantations in the study area provided mean 
RESEARCH ARTICLES

Table 3. Mean values and range of soil acidity, exchangeable bases, extractable aluminium, basic cation and aluminium saturation in different land-use systems

\begin{tabular}{|c|c|c|c|c|c|c|c|c|c|c|c|c|}
\hline \multirow{2}{*}{ Soil layer } & \multicolumn{3}{|c|}{ Forest } & \multicolumn{3}{|c|}{ Coffee } & \multicolumn{3}{|c|}{ Rubber } & \multicolumn{3}{|c|}{ Coconut } \\
\hline & Mean & \multicolumn{2}{|c|}{ Range } & Mean & \multicolumn{2}{|c|}{ Range } & Mean & \multicolumn{2}{|c|}{ Range } & Mean & \multicolumn{2}{|c|}{ Range } \\
\hline \multicolumn{13}{|l|}{$\mathrm{pH}_{(\mathrm{w})}$} \\
\hline Surface soil & 5.67 & 4.59 & 6.00 & 5.86 & 4.74 & 7.51 & 5.11 & 4.16 & 6.50 & 5.45 & 4.66 & 6.40 \\
\hline Subsoil & 5.50 & 3.60 & 6.70 & 5.50 & 4.30 & 7.20 & 5.16 & 3.94 & 5.88 & 5.53 & 4.88 & 6.00 \\
\hline \multicolumn{13}{|l|}{$\mathrm{pH}_{(\mathrm{Ca})}$} \\
\hline Surface soil & 5.08 & 4.04 & 6.00 & 5.43 & 4.27 & 7.02 & 4.53 & 3.88 & 6.02 & 4.62 & 4.14 & 5.80 \\
\hline Subsoil & 4.70 & 3.60 & 5.80 & 5.10 & 3.80 & 6.40 & 4.88 & 3.94 & 5.88 & 4.70 & 4.28 & 6.0 \\
\hline \multicolumn{13}{|l|}{ OC (\%) } \\
\hline Surface soil & 3.13 & 1.18 & 8.75 & 2.63 & 1.05 & 4.57 & 2.95 & 0.99 & 5.63 & 1.27 & 0.70 & 2.09 \\
\hline Subsoil & 0.85 & 0.15 & 4.08 & 0.85 & 0.07 & 3.94 & 1.02 & 0.02 & 4.18 & 0.67 & 0.33 & 1.4 \\
\hline Surface soil & 5.76 & 0.34 & 27.20 & 7.74 & 1.66 & 16.25 & 2.27 & 0.00 & 13.55 & 1.48 & 0.29 & 3.00 \\
\hline Subsoil & 2.15 & 0.08 & 17.73 & 3.43 & 0.14 & 17.87 & 1.31 & 0.01 & 7.62 & 1.49 & 0.31 & 3.00 \\
\hline \multicolumn{13}{|c|}{ Exchangeable magnesium $\left(\mathrm{cmol}(+) \mathrm{kg}^{-1}\right.$ soil $)$} \\
\hline Surface soil & 2.61 & 0.37 & 4.67 & 1.44 & 0.12 & 7.01 & 0.86 & 0.01 & 5.27 & 0.40 & 0.11 & 1.00 \\
\hline Subsoil & 1.39 & 0.08 & 4.71 & 1.28 & 0.05 & 15.74 & 0.65 & 0.00 & 6.76 & 0.51 & 0.11 & 1.20 \\
\hline \multicolumn{13}{|c|}{$\mathrm{KCl}$ extractable $\mathrm{Al}\left(\mathrm{cmol}(+) \mathrm{kg}^{-1}\right.$ soil $)$} \\
\hline Surface soil & 0.19 & 0.00 & 1.08 & 0.09 & 0.00 & 0.58 & 0.79 & 0.00 & 2.62 & 0.86 & 0.00 & 1.90 \\
\hline Subsoil & 0.62 & 0.00 & 13.43 & 0.36 & 0.00 & 4.01 & 0.62 & 0.00 & 2.79 & 0.46 & 0.00 & 1.45 \\
\hline \multicolumn{13}{|l|}{ BS $(\% ;$ CEC 7$)$} \\
\hline Surface soil & 61 & 5 & 100 & 71 & 29 & 100 & 30 & 2 & 100 & 33 & 11 & 98 \\
\hline Subsoil & 41 & 5 & 100 & 52 & 6 & 100 & 26 & 1 & 100 & 43 & 11 & 98 \\
\hline \multicolumn{13}{|c|}{ Al saturation (\%) } \\
\hline Surface soil & 4 & 0 & 28 & 2 & 14 & 0 & 32 & 0 & 91 & 39 & 0 & 69 \\
\hline
\end{tabular}

surface soil $\mathrm{pH}_{(\mathrm{w})}$ of 5.86 (range: 4.74-7.51) and subsoil $\mathrm{pH}_{(\mathrm{w})}$ of 5.50 (range: 4.3-7.2). The content of exchangeable bases, and exchangeable $\mathrm{Al}$ and $\mathrm{Al}$ saturation followed a trend similar to soils of natural forests.

Spatial pattern of subsoil acidity (Figure 1) showed negligible variability in coffee plantations, except in a few instances. It is apparent that conversion of natural forests to managed coffee plantations did not result in any significant increase in subsoil acidity. The external inputs of plant nutrients and amelioration of acidity generated by acid-forming fertilizers by liming prevented the depletion of subsoil bases, and acidification of surface soils and subsoils.

\section{Rubber land-use system}

Rubber (Hevea brasiliensis) was introduced to South India in 1879 and the first commercial plantation was established in Thattekkad, Kerala. The initial plantations established till 1950s were on lands cleared from forests. However, the small holder plantations established thereafter were mainly on lands converted from other uses.
Rubber plantations, unlike in the case of coffee, entailed complete clearance of forest or other plant species. For the entire life cycle of around 40 years, the plantations are monocrops of rubber, except for initial three years of the crop when annual crops like banana and pineapple are intercropped. Rubber plantations are essentially closed systems with external inputs limited to annual chemical fertilizer inputs of $750 \mathrm{~kg}$ and outgo of around 2000 $3000 \mathrm{~kg}$ per hectare of dry rubber. Zero tillage is the norm and there is practically no soil erosion from rubber plantations. The significant difference from coffee plantation management is the absence of liming to ameliorate soil acidity. This stems from the strong belief that rubber is tolerant to acidity and Al.

Analysis of the dataset of 100 soil profiles from rubber plantations in the study area provided mean surface soil $\mathrm{pH}_{(\mathrm{w})}$ of 5.11 (range: 4.16-6.50) and subsoil $\mathrm{pH}_{(\mathrm{w})}$ of 5.16 (range: 3.94-5.88) with surface soils strongly acidic in reaction and subsoils extremely acidic. The levels of organic carbon and exchangeable bases were lower in the subsoil layers. Al saturation was also high in the subsoil layers. Conversion of forests or other cropped lands to rubber plantations resulted in strong acidification of soils 

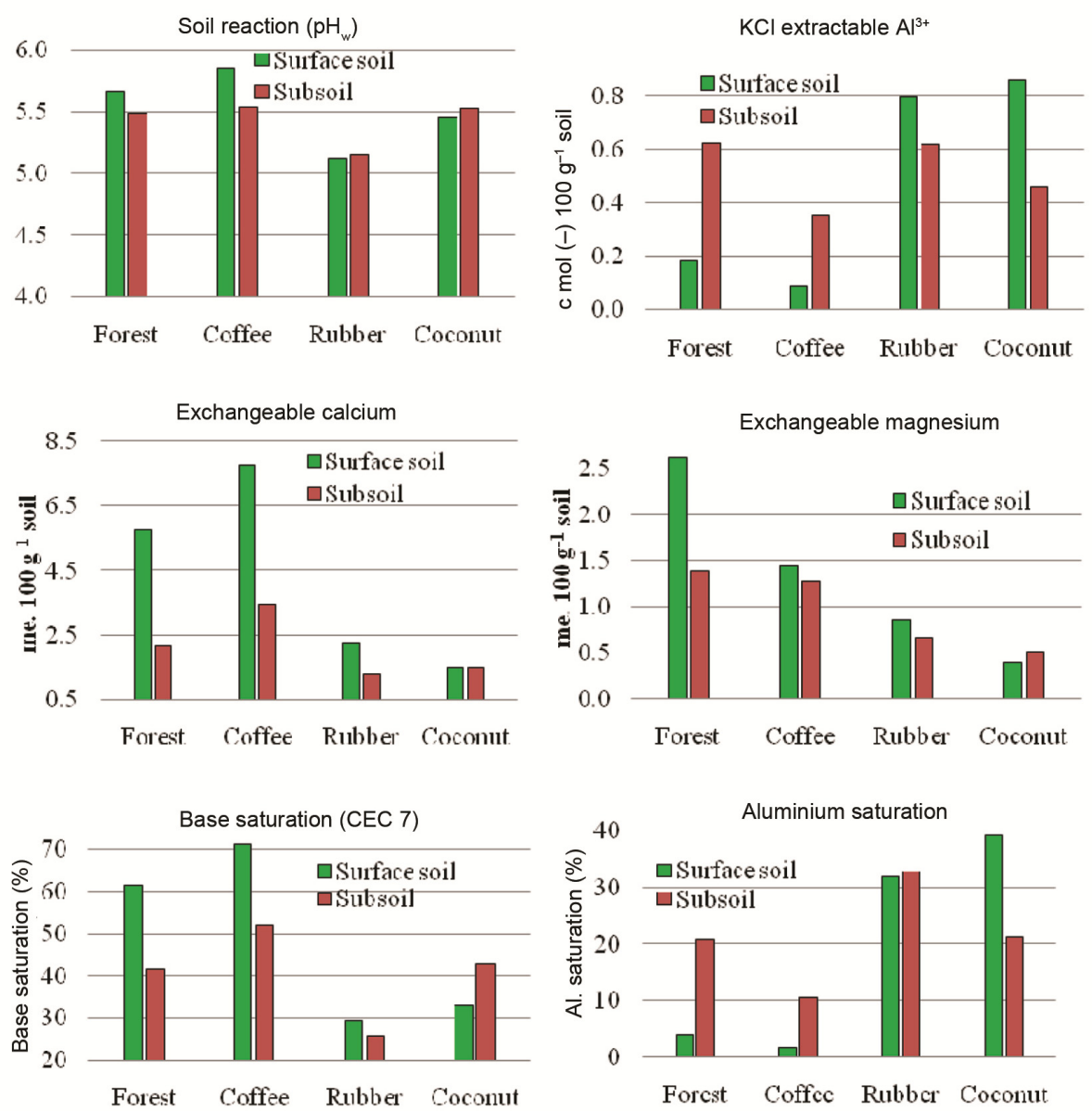

Figure 3. Variability of soil $\mathrm{pH}$, extractable $\mathrm{Al}$, exchange $\mathrm{Ca}$ and $\mathrm{Mg}$, base saturation and $\mathrm{Al}$ saturation in natural and managed land-use systems of South India.

and high levels of $\mathrm{KCl}$-extractable $\mathrm{Al}$, both in surface soil and subsoil. Strong acidification in surface soil and subsoil in rubber plantations is a consequence of external inputs of acid-producing nitrogenous fertilizers, and no liming and no calcium and magnesium inputs.

\section{Coconut land-use system}

Small-holder coconut plantation is a major land-use system in the midlands and coastal plains west of highland plateaus of the Western Ghats. The plantations are pure stands of palm mixed with other perennials and annuals or in homesteads. The decline of agriculture as the primary means of livelihood in the region has led to neglect of palms in small-holder coconut plantations ${ }^{30}$. Agronomic management and external inputs of plant nutrients for the palm have practically ceased. So also the liming of acid soils. The observed strong acidification of soils (mean surface soil $\mathrm{pH}$ of 5.45 and mean subsoil $\mathrm{pH}$ of 5.53), low content of basic cations (mean total bases in surface soil 1.88 and in subsoil 2.00) and high Al saturation of exchange complex (mean Al saturation of $39 \%$ in surface soil and $21 \%$ in subsoil) are primarily due to lack of liming for coconut and intercrops.

\section{Spatial patterns in intensity of subsoil acidity}

Classified dataset on the intensity of subsoil Al saturation for all the SQMS, natural and managed land-use systems, was plotted on a map of the study area (Figure 1). The plot revealed significant regional variability of subsoil acidity. Subsoil Al in the Malnad region of Karanataka comprising Shimoga, Chikmagalur, Kodagu and Hassan districts was practically zero or very slight, if at all. The area north of Ernakulam district to Udupi district and highlands of Wayanad plateau had a fair mix of soils with negligible, slight and strong subsoil acidity, with the last mentioned class mainly under rubber plantations. In the southern region comprising all districts south of Thrissur, most observation points recorded strong subsoil aluminium saturation. It is worth mentioning here that in the south not only managed land-use systems had strong subsoil acidity, but also natural forests (Table 3 and Figure 5). All the forest soils sampled south of Thrissur district, 

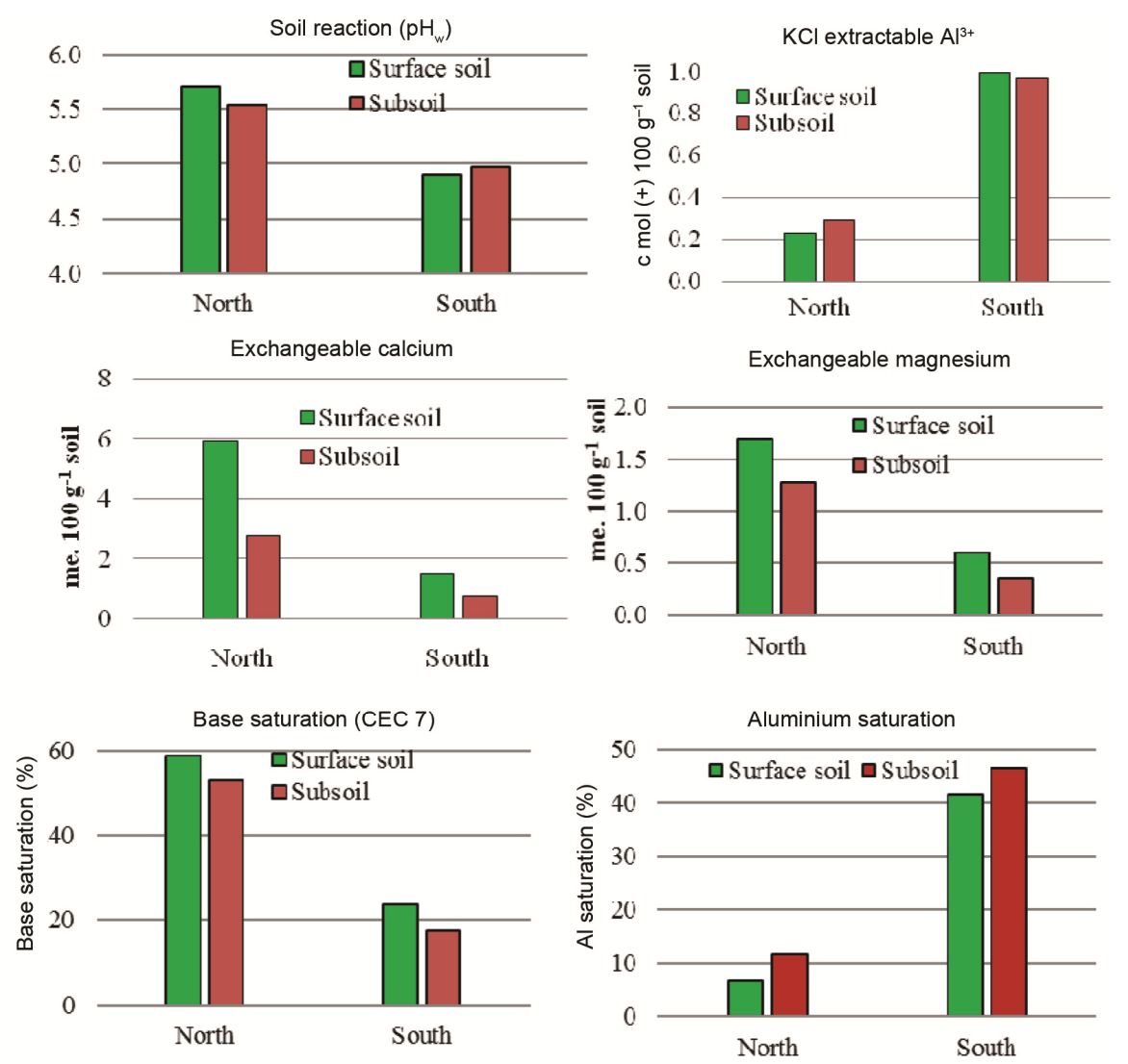

Figure 4. Regional variability of soil $\mathrm{pH}$, extractable $\mathrm{Al}$, exchange $\mathrm{Ca}$ and $\mathrm{Mg}$, base saturation and $\mathrm{Al}$ saturation.

Kerala (including the Western Ghats highlands) were strongly acidic for both surface soil and subsoil. The subsoil KCl-extractable aluminum often exceeded $0.5 \mathrm{cmol}(+) \mathrm{kg}^{-1}$ soil and $\mathrm{Al}$ saturation was above $50 \%$ for all land-use systems in the southern region (Figure 5).

\section{Consequences of soil acidification}

Acid soils are stressed environment for plant growth. They constrain plant growth by impairing the availability of nutrients ${ }^{31}$, microbial processes responsible for organic matter decomposition and nitrogen fixation ${ }^{32,33}$, and activity of macro-fauna such as earthworms ${ }^{34}$.

Subsoil acidity, in addition, is complicated by the presence of $\mathrm{Al}$ in soil solution and its effect on plant growth $^{35,36}$. Al in surface soils seldom becomes toxic to plants due to its chelation by organic matter ${ }^{37}$. Al toxicity in subsoils results in root deformation, and inhibits elongation of main axis and lateral roots ${ }^{38-41}$. Aluminium inhibits $\mathrm{Ca}$ and $\mathrm{Mg}$ uptake by blocking $\mathrm{Ca}^{+}$channels in the plasma membrane ${ }^{42}$ and by blocking sites of transport $\operatorname{protein}^{43}$.

Net effect of root injury is inefficient uptake of nutrients and water. Plant roots do not proliferate into subsoil layers with high soluble aluminium. Inability of plants to absorb water from deeper soil layers becomes critical during the annual dry period of 3-6 months in the studied area.

\section{Amelioration of soil acidity}

Amelioration of soil acidity by liming is an important agronomic management for crop production all over the world. History of liming to ameliorate soil acidity dates back to the 19 th century ${ }^{44,45}$. During the 20th century liming of acid soils became a common practice and lime rate recommendations an integral part of soil-testing services. Acidity and Al toxicity in surface soil can be ameliorated through liming: incorporating liming materials such as ground limestone (calcite: $\mathrm{CaCO}_{3}$ ), burnt lime $(\mathrm{CaO})$ or dolomite $\left(\mathrm{CaCO}_{3} \cdot \mathrm{MgCO}_{3}\right)$ into soil by tillage. $\mathrm{Ca}$ and $\mathrm{Mg}$ carbonates react with $\mathrm{H}^{+}$ions formed from hydrolysis of $\mathrm{Al}^{3+}$ and exchangeable aluminium ${ }^{46}$.

The carbonates of $\mathrm{Ca}$ and $\mathrm{Mg}$ incorporated into surface soil, however, have little effect on subsoil acidity because of the low solubility of materials and consequent low mobility ${ }^{47}$. Subsoil incorporation of lime by deep ploughing or using specialized equipment ${ }^{48,49}$ is not a feasible option, especially in plantations. On the other hand surface-applied gypsum (a partially soluble salt) moves down the soil in the leaching regime of humid environment, and in the process increases labile Ca levels and decreases Al in subsoil layers ${ }^{9,10,47,50}$. Ameliorative effect of gypsum is due to one or more of the following mechanisms: (i) more labile calcium in subsoil, (ii) formation of $\mathrm{Al}$ sulphates and precipitation ${ }^{51}$, and (iii) 'self liming' through ligand exchange of $\mathrm{SO}_{4}$ for $\mathrm{OH}^{+}$on sesquioxides. 


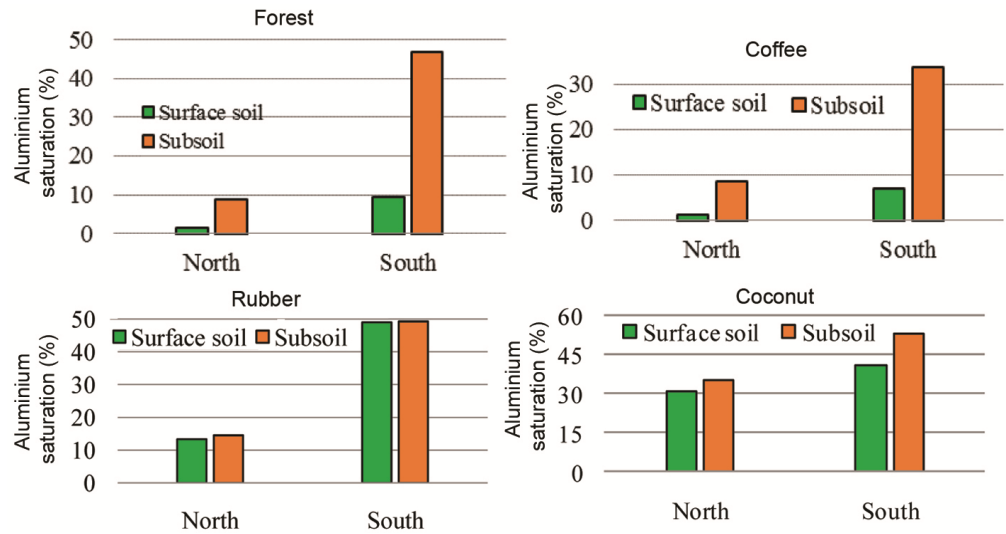

Figure 5. Mean aluminium saturation surface soil and subsoil in natural and managed land-use systems of northern and southern regions in the study area.

The decrease in $\mathrm{Al}$ and corresponding increase in $\mathrm{Ca}$ in subsoil layers by gypsum treatment promote root penetration into subsoil layers, and enable plants to better extract nutrients and water. This is particularly advantageous in humid tropics with annual dry season.

Gypsum application rate of 5 tonnes/ha has been found to be effective in Brazilian Oxisols. The residual effect of a single application was reported to last for 4-6 years ${ }^{52}$. However, this rate was found insufficient for less intensively weathered, but equally acidic, Ultisols of South Africa $^{53,54}$. Ultisols differ from Oxisols in containing greater absolute amounts of exchangeable Al and potentially active Al (Table 2) associated with mixed-layer clay mineralogy ${ }^{55}$. Replenishment of $\mathrm{Al}^{3+}$ from this exchangeable source is responsible for the high lime and gypsum requirement of Ultisols, often in the range 510 tonnes/ha for lime and 10-15 tonnes/ha for gypsum ${ }^{53}$.

\section{Conclusion}

Soil acidity (both surface soil and subsoil) is pervasive in natural and managed land-use systems of the humid tropical southern India. In natural forest ecosystem, subsoil acidity is of serious concern only in land areas south of Thrissur district in Kerala. Tree plantations established in forests of this region are affected by subsoil aluminium and deficiency of calcium and magnesium. The managed land-use systems, however, have absolute requirement of regular amelioration of surface soil and subsoil acidity. The appropriate strategy for simultaneous amelioration of surface and subsoil acidity is incorporation of ground limestone and gypsum to surface soil. It is desirable to use dolomite limestone containing $\mathrm{Ca}$ and $\mathrm{Mg}$, as heavy loading of $\mathrm{Ca}$ through lime and gypsum inputs is likely to deplete surface soil reserve of $\mathrm{Mg}$ and affect plant growth. Again, for best effects in terms of biomass production and economic crop yields, amelioration of soil acidity should be followed by optimum plant nutrient inputs.
1. Von Uexkull, H. R. and Mutert, E., Global extent, development and economic impact of acid soils. Plant Soil, 1995, 171, 1-5.

2. Van Wambeke, A., Formation, distribution and consequences of acid soils in agricultural development. In Proceedings of the Workshop on Plant Adaptation to Mineral Stress in Problem Soils (eds Wright, M. J. and Ferrari, S. A.), Special Publication Cornell University, Agric. Exp. Stn., Ithaca, NY, USA, 1976, pp. 15-24.

3. Eswaran, H., Soil and site characterization for soil-based research network. In Soil Management Under Humid Conditions in Asia (ASIALAND), IBSRAM, Bangok, 1987, p. 169.

4. Maji, A. K., Obi Reddy, G. P. and Meshram, S., Acid soil map of India. Annual Report, ICAR-National Bureau of Soil Survey and Land Use Planning (ICAR-NBSS\&LUP), Nagpur, 2008.

5. Hede, A. R., Skovmand, B. and Lopez-Cesati, J., Acid soil and aluminium activity toxicity, In Application of Physiology in Wheat Breeding. International Maize and Wheat Improvement Center (eds Reynolds, M. P., Ortiz-Monasterio, J. J. and Mchab, A.), CIMMYT, Mexico, 2001, pp. 172-182.

6. Rengel, Z., Uptake of aluminium by plant cells. New Phytol., 1996, 134, 389-406.

7. Mora, M. L., Alfaro, M. A., Jarvis, S. S., Demanet, R. and Cartes, P., Soil aluminium availability in Andisols of southern Chile and its effect on forage production and animal metabolism. Soil Use Manage., 2006, 22, 95-101.

8. Adams, F., Soil Acidity and Liming, American Society. Agronomy, Crop Science Society of America (CSSA) and Soil Science Society of America (SSSA), Madison, Wisconsin, USA, 1984, 2nd edn.

9. Sumner, M. E., Aluminium toxicity - growth limiting factor in some Natal sands. Proc. Suga. Afr. Su. Technol. Assoc., 1970, 44, $1-6$.

10. Reeve, N. G. and Sumner, M. E., Amelioration of subsoil acidity in Natal Oxisols by leaching of surface applied amendments. Agrochemophysica, 2006, 4, 1-6.

11. Clark, R. B., Physiological aspects of calcium, magnesium and molybdenum deficiencies in plants. In Soil Acidity and Liming (ed. Adams, F.), Agron. Monograph, ASA, CSSA and SSSA, Madison, WI, USA, 1984, vol. 12, pp. 99-170.

12. Kumar Roy, A., Sharma, A. and Talukder, G., Some aspects of aluminium toxicity in plants. Bot. Rev., 1988, 54, 145-178.

13. Panda, S. K., Singha, L. B. and Khan, M. H., Does aluminium phytotoxicity induce oxidative stress in greengram (Vigna radiata). J. Plant Physiol., 2003, 29, 77-86.

14. Poschenrieder, C., Gunse, B., Corrales, I. and Barcelo, J., A glance into aluminium toxicity and resistance in plants. Sci. Total Environ., 2008, 400, 356-368.

15. Fouche, P. S. and du Sautoy, N., Influence of surface applied lime and gypsum on subsoil acidity, extractable calcium and nutrient 
accumulation in Avacoado (Persea Americana Mill.). In South African Avocado Grower's Association Yearbook, 1995, vol. 18, pp. $12-16$.

16. Blue, W. G. and Dantzman, C. L., Soil chemistry and root development in acid soils. Soil Crop Sci. Fla. Proc., 1976, 36, 9-15.

17. Rechcigl, J. E., Reneau Jr, R. R. and Starner, D. E., Effect of subsurface amendments and irrigation on alfalfa growth. Agron. J., 1985, 77, 72-75.

18. Raji, B., Improving the root environment in the subsurface. In Boas Practicas para USO Eficiente de Fertilizantes (eds Prochnow, L. I. et al.), International Plant Nutrition Institute, United States, 2010, pp. 349-382.

19. Nair, K. M. et al., Agro-Ecology of Kerala, NBSS Publ. No. 1038, NBSS\&LUP, Nagpur, 2011.

20. Anil Kumar, K. S. et al.; Soil Quality Monitoring Sites (SQMS) for Traditional Rubber-Growing Areas of South India, NBSS Publ. No., NBSS\&LUP, Nagpur, 2016.

21. Nair, K. M. et al., Soil Quality Monitoring Sites (SQMS) for Traditional Coffee-Growing Areas of India, NBSS Publ. No., National Bureau of Soil Survey and land Use Planning, Nagpur, 2016.

22. Soil Survey Staff, Soil Taxonomy: A Basic System of Soil Classification for Making and Interpreting Soil Surveys. United States Department of Agriculture-National Resources Conservation Services, Agriculture Handbook, 436, US Government Printing Office, Washington DC, USA, 1999, 2nd edn.

23. Jackson, M. L., Soil Chemical Analysis, Prentice Hall of India (Pvt) Ltd, New Delhi, 1973.

24. Piper, C. S., Soil and Plant Analysis, Hans Publishers, Bombay, 2002.

25. Sparks, Methods of Soil Analysis Part-II: Chemical Methods, Soil Science Society of America, USA, 1996.

26. Chandran, P., Ray, S. K., Bhattacharyya, T., Srivastava, P., Krishnan, P. and Pal, D. K., Laterite soils of Kerala, India: their mineralogy, genesis and taxonomy. Aust. J. Soil Res., 2005, 43, 839-852.

27. Sposito, G., The Environmental Chemistry of Aluminum, CRC Press, Florida, USA, 2000.

28. Herrera, R., Jordan, C. F., Klinge, H. and Medina, E., Amazon ecosystems. Thei structure and functioning with particular emphasis on nutrients. Intersciencia, 1978, 3(4), 223-231.

29. Herrera, R., Jordan, C. F., Medina, E. and Klinge, H., How human activities disturb nutrient cycles of a tropical rainforest in Amazonia. Ambio., 1981, 10(2-3), 109-114.

30. Kannan, K. P., Agricultural development in an emerging non-agrarian regional economy: Kerala's challenges. Econ. Polit. Wkly. XLVI, 2011, 9, 64-70.

31. Kemmit, S. J., Wright, D., Goulding, K. W. T. and Jones, D. L., $\mathrm{pH}$ regulation of carbon and nitrogen dynamics in two agricultural soils. Soil Biol. Biochem., 2006, 38, 898-911.

32. Rousk, J., Brooks, P. C. and Baath, E., Contrasting soil pH effects on fungal and bacterial growth suggest functional redundancy in carbon mineralization. Appl. Environ. Microbiol., 2009, 75(6), 1589-1596.

33. Bru, D., Ramette, A., Saby, N. P. A., Dequidt, S., Ranjard, L., Jolivet, C. and Arrouays, D., Determinants of the distribution of nitrogen-cycling microbial communities at the landscape scale. ISME J., 2011, 5, 532-542.

34. Lavelle, P., Chauvel, A. and Fragoso, C., Faunal activity in acid soils. In Plant Soil Interactions at Low pH (eds Date, R. A. et al.), Kluwer, The Netherlands, 1955, pp. 201-211.

35. Adams, F., Nutrient importance and constraints in acid soils J. Plant Nutr., 1981, 444, 81-88.

36. Nair, K. M. and Chamuah, G. S., Exchangeable aluminium in soils of Meghalaya and management of $\mathrm{Al}^{3+}$ related productivity constraints. J. Indian Soc. Soil Sci., 1993, 41, 331-334.
37. Bloom, P. R., McBride, M. B. and Weaver, R. M., Aluminium organic matter interactions in acid soils: salt-extractable aluminiun. Soil Sci. Soc. Am. J., 1979, 43, 813-815.

38. Koltz, F. and Hortz, W. J., Genotype differences in aluminium tolerance of soybean (Glycine max. L.) as affected by ammonium and nitrate nitrogen nutrition. J. Plant Physiol., 1988, 132, 702-707.

39. Foy, C. D., Chaney, R. L. and White, M. C., The physiology of metal toxicity in plants. Annu. Rev. Plant Physiol., 1978, 29, 511566.

40. Foy, C. D., Physiological effects of hydrogen, aluminium and manganese toxicities in acid soil. In Soil Acidity and Liming (ed. Adams, F.), American Society of Agronomy, Madison, WI, USA, 1984, pp. 57-97.

41. Marchner, H., Mechanisms of adaption of plants to acid soils. Plant Soil, 1991, 134, 1-24.

42. Huang, J. W., Shaff, J. E., Grunes, D. L. and Kochian, L. V., Aluminium effects on calcium fluxes at the root apex of aluminium tolerant and aluminium sensitive wheat cultivars. Plant Physiol., 1992, 98, 230-237.

43. Rengel, Z. and Robinson, D. L., Aluminium effects on growth and macronutrient uptake by annual ryegrass. Agron. J., 1989, 81, 208-215.

44. Thomas, G. W., Historical developments in soil chemistry: ion exchange. Soil Sci. Soc. Am. J., 1977, 41, 230-238.

45. Coleman, N. T., Kamprath, E. J. and Weed, S. B., Liming. $A d v$. Agron., 1959, 10, 475-522.

46. Thomas, G. W. and Hargrove, W. I., The chemistry of soil acidity. In Soil Acidity and Liming (ed. Adams, F.), American Society of Agronomy, Madison, WI, USA, 1984, pp. 3-56.

47. Shainberg, I., Sumner, M. E., Miller, W. P., Farina, M. P. W., Pavan, M. A. and Fey, M. V., Use of gypsum on soils: a review. Adv. Soil Sci., 1989, 9, 1-111.

48. Farina, M. P. W. and Channon, P., Acid subsoil amelioration, 1. A comparison of several mechanical procedures. Soil Sci. Soc. Am. $J .$, 1988, 52, 169-175.

49. Jayawardane, N. S., Barrs, H. D., Muirhead, W. A., Blackwell, J., Murray, E. and Kirchof, G., Lime slotting technique to ameliorate subsoil acidity in clay soil: II Effect on medic root growth, water retention and yield. Aust. J. Soil Res., 1995, 33, 443-459.

50. Richey, K. D., Souza, D. M. G., Lobato, E. and Correa, O., Calcium leaching to increase rooting depth in Brazilian Savanna Oxisol. Agron. J., 1980, 72, 41-44.

51. Pavan, M. A., Bingham, F. T. and Pratt, P. F., Redistribution of exchangeable calcium, magnesium and aluminium following lime or gypsum application to Brazilian Oxisol. J. Soil Sci. Soc. Am., 1984, 48, 33-38.

52. Ritchy, K. D., Feldhake, C. M., Clark, R. B. and Sousa, D. M. G., Improved water and nutrient uptake from subsurface layers of gypsum amended soils. In Agricultural Utilization of Urban and Industrial By-products, ASA Spec. Publ. 58. ASA, Madison, WI, USA, 1995, pp. 157-181.

53. Farina, M. P. W., Management of subsoil acidity in environments outside humid tropics. In Plant-Soil Interactions at Low pH: Sustainable Agriculture and Forestry Production (eds Moniz, A. C. et al.), Brazilian Soil Science Society, Campinas, Brazil, 1997, pp. 179-190.

54. Farina, M. P. W., Channon, P. and Thibaud, G. R., A comparison of strategies for ameliorating subsoil acidity. I. Long term growth effects. Soil Sci. Soc. Am. J., 2000, 64, 646-651.

55. Juo, A. S. R. and Kamprath, E. J., Copper chloride as an extractant for estimating potentially reactive aluminium pools in acid soils. Soil Sci. Soc. Am. J., 1979, 43, 35.

Received 15 May 2017; revised accepted 7 January 2018

doi: $10.18520 / \mathrm{cs} / \mathrm{v} 116 / \mathrm{i} 7 / 1201-1211$ 